\title{
Human-environment interactions in mountain rainforests: archaeobotanical evidence from central Sulawesi, Indonesia
}

\author{
Wiebke Kirleis $\cdot$ Valério D. Pillar $\cdot$ Hermann Behling
}

Received: 7 April 2010/Accepted: 5 October 2010/Published online: 4 November 2010

(C) The Author(s) 2010. This article is published with open access at Springerlink.com

\begin{abstract}
Palaeoecology may contribute to the debate on nature conservation and the preservation of cultural heritage. Here we present two palaeo-records from the Lore Lindu Biosphere Reserve and National Park in central Sulawesi, Indonesia. The park comprises one of the largest remaining and most biodiverse mountain forests of Sulawesi. Outstanding megalithic sites reveal long-term human impact on the area. Thus, modern vegetation composition within the park has been determined by complex site histories, natural and anthropogenic. Palaeo-records from sites between 1,000 and 1,400 m a.s.l. demonstrate that human activity as well as climate variations have to be considered as the main drivers of vegetation changes in the region for the last 2,000 years. Human impact is reflected by large amounts of charred fragments in the pollen records plus low values of arboreal pollen resulting from forest clearance. The stratigraphy of one of the pollen records shows effects of a general cooling trend during the Little Ice Age (LIA). Biomass loss due to the conversion of lower
\end{abstract}

Communicated by Y. Yasuda.

\section{W. Kirleis $(\square)$}

Institute for Prehistoric and Protohistoric Archaeology/

Graduate School Human Development in Landscapes,

Christian-Albrechts-University Kiel,

Johanna-Mestorf-Straße 2-6, 24098 Kiel, Germany

e-mail: wiebke.kirleis@ufg.uni-kiel.de

\section{D. Pillar}

Departamento de Ecologia, Universidade Federal do Rio Grande do Sul, Porto Alegre, RS 91540-000, Brazil

H. Behling

Palynology and Climate Dynamics, Albrecht-von-Haller Institute for Plant Sciences, Georg-August-University Göttingen, Untere Karspüle 2, 37073 Göttingen, Germany montane rainforest to grassland has reduced the carbon storage potential in the area of the Lore Lindu Park. Recommendations for conservation policy that may be made from the environmental history within the biosphere reserve thus include the consideration of human influence in easily accessible areas, particularly in face of recent settlement intensification.

Keywords Indonesia $\cdot$ Archaeology $\cdot$ Vegetation history · Climate change $\cdot$ Fire history $\cdot$ Nature conservation

\section{Introduction}

Modern slash-and-burn clearance by extractive industries endangers tropical forests in different parts of the world and leads towards a world of degraded and low biodiversity post-forest habitats where indigenous peoples have a minimal role to play and are deprived of many resources. In central Sulawesi, the Lore Lindu area has been listed as a UNESCO Man and Biosphere Reserve since 1978 and was established as a national park in 1993 (The Nature Conservancy Indonesia Program ca. 2004). The park protects a unique montane rainforest area with $90 \%$ of its canopy cover still intact. Villagers within and surrounding the park have used its resources over generations to a sustainable extent. However, recently new settlers have encroached on the park area. Because of rising population density, the forest and its wildlife are increasingly threatened by agricultural conversion and illegal harvesting of forest resources (The Nature Conservancy Indonesia Program ca. 2004; Erasmi et al. 2004).

Within Indonesia, Sulawesi is one of the most important but poorly known ecoregions. The large oceanic island is situated at the bio-geographic crossroad between East Asia 
and Australasia, which is underlain by a complex geology. These facts have resulted in a high level of endemism, especially for the fauna (Cannon et al. 2007; Whitten et al. 1987). The Lore Lindu area in central Sulawesi possesses a unique biodiversity (Keßler et al. 2002; Whitten et al. 1987; Culmsee and Pitopang 2009; Culmsee et al. 2008) and a rich cultural heritage of ancient stone megaliths (Sukendar 1997; Yuniawati 2001).

To better understand the modern composition of the vegetation cover and to corroborate the development of nature conservation strategies in the Lore Lindu area, we offer a palaeoecological perspective that reveals long-term dynamics of human-environment interactions. We present results of pollen analyses of two sediment cores from the Besoa valley in the south of the Lore Lindu Park. Additional information on local prehistory and environmental history is available from megalithic sites in the Besoa valley and sediment cores from the lakes Kalimpaa and Lindu situated about $25 \mathrm{~km}$ further north in the park (Cook et al. 2008). Investigations were carried out within the framework of the interdisciplinary German-Indonesian Collaborative Research Centre "Stability of Rainforest Margins in Indonesia" (STORMA) funded by the German Research Foundation (DFG). STORMA is focusing on the biological and ecological degradation of rainforest margin areas in the Lore Lindu National Park and Biosphere Reserve and develops strategies to stabilise these interfaces (Gerold et al. 2004; Tscharntke et al. 2007).

\section{Study region}

The study was conducted in the south of the Lore Lindu National Park, central Sulawesi, Indonesia (Fig. 1). In central Sulawesi the climate is best characterised with reference to annual rainfall patterns, and it is perhumid with at most 2 months per year receiving $<100 \mathrm{~mm}$ rainfall on average. In the Besoa valley annual precipitation is about 2,000 $\mathrm{mm}$. Yearly temperature variations are relatively low due to the tropical conditions, and the annual mean temperature is about $19^{\circ} \mathrm{C}$ (Culmsee et al. 2008, 2010).

The Lore Lindu Park covers an area of about 218,000 ha and comprises one of the largest remaining mountainous rainforests of Sulawesi. The vegetation gradient ranges from lowland rainforests below 1,000 $\mathrm{m}$ to upper montane and elfin forests above $2,000 \mathrm{~m}$. Upland and montane forests growing on intermediate soils cover most parts of the Lore Lindu Park. Fagaceae, especially Castanopsis and Lithocarpus species, form the most prominent part of the mountain forests of Sulawesi (Goeltenboth et al. 2006). Above ground biomass (AGB) estimates of three plots in the Lore Lindu area show that the Fagaceae are dominant in the submontane, lower montane and mid-montane forests that range in altitude from 1,050 to $1,800 \mathrm{~m}$ a.s.l. (Culmsee et al. 2010). Submontane forest at an elevation of $1,050 \mathrm{~m}$ a.s.l. is characterised by high frequencies of Fagaceae, Sapotaceae, Moraceae, Lauraceae and Myrtaceae. Lesser components include Euphorbiaceae, Meliaceae, Burseraceae, Elaeocarpaceae, Clusiaceae, Icacinaceae, Myristicaceae, Annonaceae, Asteraceae and Rosaceae (listed in descending order). These families together contribute to about $90 \%$ of the total AGB estimates for a submontane site in the south of the park. Towards higher altitudes a decrease in tree species richness is observed. Lower montane forest at an altitude of 1,400 m a.s.l. is mainly composed of Fagaceae, Burseraceae, Myrtaceae, Sapotaceae, Elaeocarpaceae, Clusiaceae, Oleaceae, Lauraceae and Icacinaceae, all listed in descending order. At a mid-montane site at 1,800 $\mathrm{m}$ a.s.l. a change towards dominance by species of Fagaceae followed by Myrtaceae, Magnoliaceae, Theaceae, Styracaceae, Hamamelidaceae and Juglandaceae is recorded. An upper montane forest at 2,400 m a.s.l. is dominated by the tree families Podocarpaceae, Myrtaceae and Fagaceae, again listed in descending order (Culmsee et al. 2008, 2010). Easily accessible areas like the main valleys are characterised by widespread grasslands of the Poaceae tribe Andropogoneae, Pteridium aquilinum (bracken fern) and areas under rice cultivation.

\section{Research on vegetation history in the region}

Palaeoecological studies from Indonesia on mid to late Holocene vegetation history are rare. There is particular need for high resolution pollen records to shed light on past interactions between humans and environment, and to trace climate change. So far, palaeoecological studies on terrestrial material have been carried out in Borneo (Hunt and Rushworth 2005), Halmahera (Suparan et al. 2001), Java (van der Kaars and van den Bergh 2004; van der Kaars et al. 2001; Stuijts 1993), Kalimantan (Anshari et al. 2001; Yulianto et al. 2005), New Guinea (Haberle et al. 1991; Hope 1983), Sumatra (Maloney 1990) and Sulawesi (Gremmen 1990; Hope 2001; Dam et al. 2001). Marine cores provide additional information on past vegetation and climate dynamics (van der Kaars 1991, 1998; van der Kaars et al. 2000, 2010; Wang et al. 1999). Most of these investigations discuss long lasting variations in the climate regime and are in an unsatisfactory temporal resolution, because the number of counted samples is low compared to the time span.

Pollen results from a sediment core of Lake Tondano, north Sulawesi, show the vegetation history of the last 33,000 years. Research concentrated on the shift from Late Pleistocene to the Holocene. Whereas low precipitation and low mean temperatures were indicated during the Pleistocene, wet and warm atmospheric conditions occurred at the transition to the Holocene. The latter has led to rising lake 
Fig. 1 Study area and location of the Lore Lindu National Park in central Sulawesi, Indonesia

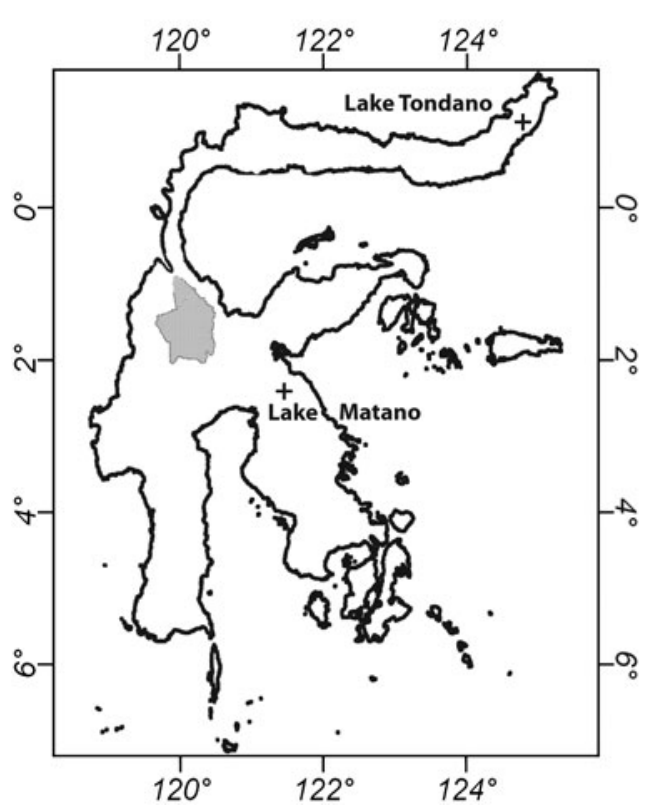

levels and a spread of forest cover. From the early mid Holocene onwards, vegetation development was disturbed mainly due to volcanic activity and to a lesser extent by human impact (Dam et al. 2001).

Pollen analysis of a peat core from a mire close to lake Matano, south Sulawesi, shows vegetation development during the last 50,000-75,000 years. During the last glacial maximum (LGM) at about 20,000 years ago, montane forest grew around the site. Large amounts of grass and Casuarina pollen suggest dry climatic conditions for this period. During the Holocene, plant diversity has increased and a lower altitude forest has established. Fine charcoal occurs throughout the whole record. As there is no indication for any human activity, the charred particles show that the forest has never been continuously free of natural fires for a long period of time (Hope 2001).

\section{Prehistory of Sulawesi}

The chronology of prehistory in Sulawesi is fragmentary (Bellwood 2007a). In eastern Indonesia, the late Pleistocene and early Holocene sites of south Sulawesi provide the earliest records of prehistory. The oldest absolute dates of related stone tools from the stage of hunters and gatherers are from the cave Leang Burung, 29000-17000 в.P. The most recognised prehistoric industry of eastern Indonesia is the Toalian that appeared about 8000 B.P. on the southwestern arm of Sulawesi. Sites like the cave Ulu Leang have yielded typical microliths in the form of flakes and geometric microliths (Bellwood 2007a). Cave paintings of unknown age may correspond to Toalian artefacts. Plant domestication and animal husbandry seem to have started by ca. 4500 в.Р. A new pottery type similar to the western Pacific Lapita occurred around 3000 B.P. in the southern and central Sulawesi sites Ulu Leang 2 and Kalumpang. By late prehistoric times, sophisticated metalworking techniques were developed (Miksic 1996). Artefacts of this period are megaliths in form of cylindrical stone vats with heights up to 1.7 and $1.2 \mathrm{~m}$ in diameter, large statues and mortars. The Metal Age megaliths were mainly erected in the central Sulawesi Besoa and Bada valleys. The vats were probably used as multiple burial chambers, and they have modelled and carved decorations of faces, figures, monkeys and lizards (Kaudern 1938; Sukendar 1980a, b; Sukendar 1997; Whitten et al. 1987; Yuniawati 2001). Similar artefacts are known from Borneo (Arifin and Sellato 2003) and from Laos (Colani 1935). In modern times, a megalithic culture is still alive in Sa'dang Toraja in south Sulawesi where people erect large stones in rows or a circle (Whitten et al. 1987).

\section{Materials and methods}

Settings of the coring locations

The investigated profiles Bariri Tower (BT), Pokekea (POK) and short cores of the sediment content of two megalithic stone vats were collected in the Besoa valley, central Sulawesi, during a sampling campaign in August 2006 (Table 1). Intact montane rainforest grows in the surroundings of the valley. Remnants of floodplain forest accompany the river Lumamba (Fig. 2). The central part of the Besoa valley is characterised by open grassland 
Table 1 Coring locations

\begin{tabular}{llll}
\hline Profile/site & Latitude & Longitude & $\begin{array}{l}\text { Elevation } \\
\text { (m a.s.1.) }\end{array}$ \\
\hline BT & S $01^{\circ} 39.247^{\prime}$ & E $120^{\circ} 11.364^{\prime}$ & $1,331 \pm 9$ \\
POK & S $01^{\circ} 41.530^{\prime}$ & E $120^{\circ} 12.758^{\prime}$ & $1,213 \pm 8$ \\
Pokekea (stone vats) & S $01^{\circ} 41.494^{\prime}$ & E $120^{\circ} 12.797^{\prime}$ & $1,220 \pm 7$ \\
\hline
\end{tabular}

vegetation and areas of paddy culture. The sediment core BT was taken in a slightly moist depression within the forest margin grassland in the Besoa valley. Thus, it offers the opportunity to show long-term vegetation dynamics at the interface of rainforest and open area. The profile POK was taken from the floodplain of the meandering rivers
Lumamba and Lengi in the vicinity of the megalithic site of Pokekea (Fig. 2). To find a pollen archive adjacent to a prehistoric site is an exceptional case that owes great potential to trace human impact directly on the vegetation. Cores were taken with a Russian type peat corer that measured $5 \mathrm{~cm}$ in diameter and $50 \mathrm{~cm}$ in length. Cores were wrapped in the field, brought to the laboratory at the University of Göttingen and stored at $+4^{\circ} \mathrm{C}$ in a cold room.

Archaeobotanical analysis

The cores have been analysed for pollen, macro remains and micro-charcoal using standard methods. For pollen analysis, 21 subsamples were selected at regular intervals from the profile $\mathrm{BT}(117 \mathrm{~cm})$ and 36 subsamples from the
Fig. 2 Besoa valley, central Sulawesi, Indonesia: locations of pollen profiles and archaeological finds. 1 Bariri Tower, BT; 2 Pokekea, POK; 3 Pokekea, archaeological site

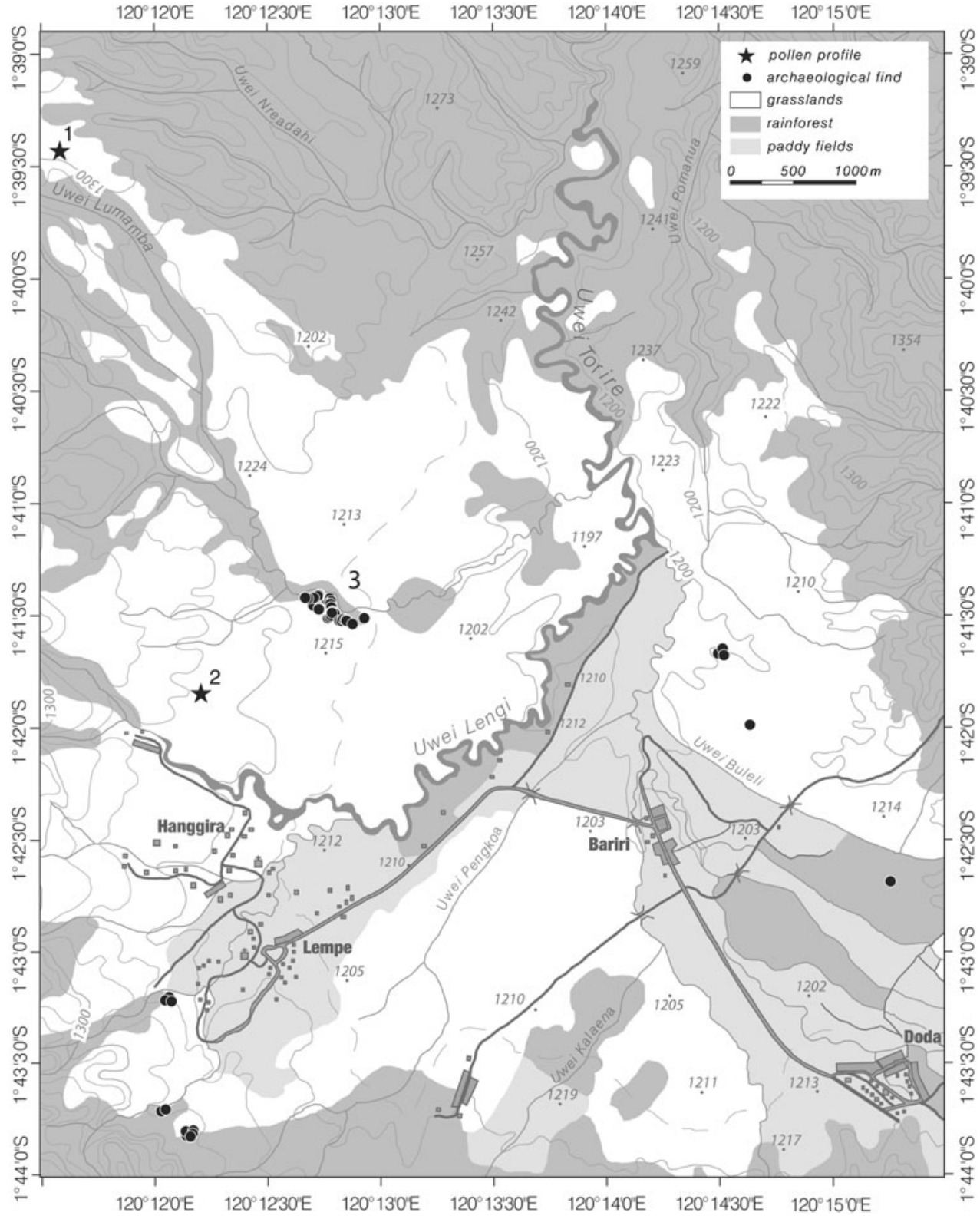


profile POK $(328 \mathrm{~cm})$. The subsamples were sieved on a $6 \mu \mathrm{m}$ mesh. The $>6 \mu \mathrm{m}$ fraction was treated with hydrochloric acid ( $\mathrm{HCl})$ prior to acetolysis (Fægri et al. 1989). Remaining silica was removed by adding hydrofluoric acid (HF) to the subsamples. Added exotic Lycopodium spores prior to processing allowed calculation of pollen and charred fragment concentrations. Slides were mounted with glycerine jelly and counted along evenly spaced transects on a Nikon Eclipse 50i microscope with Plan-Apochromat $60 \times / 1.4$ oil and Plan $100 \times / 1.25$ oil objectives. Due to difficult pollen preservation, up to 200-300 terrestrial pollen grains were counted per subsample. Microfossil identification relied on the reference collection of tropical pollen and spores at the Department of Palynology and Climate Dynamics, Göttingen University, pollen morphological descriptions and pollen keys for southeast Asia (Huang 1972; Garrett-Jones 1979; Flenley 1967; Powell 1970; Stevenson 2000) and the online Australasian Pollen and Spore Atlas (APSA) hosted at Palaeoworks, Australian National University, Canberra (http://apsa.anu.edu.au/). The results of pollen analysis are shown as percentage diagrams of a total terrestrial pollen sum that includes taxa of trees, shrubs and terrestrial herbs. Aquatic taxa as well as fern and moss spores were excluded. Pollen counts of Castanopsis and Lithocarpus were combined as Castanopsis type group as there is a large variety of Castanopsislike pollen (Stuijts 1993). Unidentifiable pollen grains due to bad state of preservation are counted as "Indeterminable" whereas unknown pollen types are referred to as "Varia". Pollen and charred fragment concentrations are expressed in the diagrams as counts per unit volume of sediment. In the summary diagrams, tree and palm taxa are grouped and pollen types of terrestrial herbs are combined into one "grasslands" group. All diagrams are divided into local pollen assemblage zones by considering major changes in the composition of the pollen assemblages. For plotting and calculations the TILIA and TILIAGRAPH software was used (Grimm 1990). Radiocarbon ages provide the chronostratigraphic framework of the pollen records. Radiocarbon dates were calibrated with the Calib radiocarbon calibration program based on the dataset for the southern hemisphere (Stuiver and Reimer 1993; McCormac et al. 2004).
Multivariate analysis

Eigenanalysis, in particular principal coordinates analysis performed on Euclidean distances between subsamples after square root transformation of pollen counts, was used to map a time series of pollen and spore percentages of the BT profile BT-1 into a full dimensional ordination to create a lower dimensional view of compositional transitions in the palaeo-community based on the most important 26 plant taxa. The significance of the ordination axes was evaluated by bootstrap re-sampling (Pillar 1999). The analyses were performed by MULTIV software (Pillar 2006).

\section{Results and interpretation}

Pollen profile BT

\section{Sedimentology and chronology}

The sediment of profile BT consists of two main units. The boundary is marked by an obvious change in the sediment colour at $87 \mathrm{~cm}$ depth. The basal part $(117-87 \mathrm{~cm})$ is silty clay, and the organic content is poor (Table 2). Conditions for pollen preservation in this section are bad and hinder the counting below $103 \mathrm{~cm}$ core depth. Pollen concentrations are very low and the occurrence of monolete spores without perispore suggests the decay of organic material. This is probably related to the former soil deposits from a forest environment with partly oxidising conditions. The silty clay of the upper unit $(87-0 \mathrm{~cm})$ has a large organic component, with fine roots, fragments of tissues and seeds/ fruits. Numerous charred fragments are responsible for the dark brown to black colour, Munsell soil colour chart 5 YR, 2.5/1, black. The sediment contains calcium carbonate $\left(\mathrm{CaCO}_{3}\right)$ as shown by a positive reaction on adding $\mathrm{HCl}$.

The results of radiocarbon dating are shown in Table 3. The age of the oldest sediment layer of this core is about 9480 cal. B.P. (7530 cal. B.C.) and comes from the section with very bad pollen preservation and low pollen concentrations, so it is not included in the linear interpolation. Subsample ages were calculated with TILIA (Grimm 1990)

Table 2 Stratigraphy of the Bariri Tower profile, BT; colour according to Munsell soil colour chart 5

\begin{tabular}{llll}
\hline Depth $(\mathrm{cm})$ & Colour & Facies & Macro remains \\
\hline $0-87$ & YR, 2.5/1 (black) & $\begin{array}{c}\text { Organic, calcareous, fine } \\
\text { grain sand on } 21 ; 29-33 ; 37-87 \mathrm{~cm}\end{array}$ & $\begin{array}{c}\text { Charred grass fragments, fine roots, fragments of plant tissues, } \\
\text { fruits of Asteraceae, Poaceae and Cyperaceae, } \\
\text { indeterminable seeds, insect remains }\end{array}$ \\
$87-117$ & YR, 8/1 (white) & Clay with fine grain sand & - \\
\hline
\end{tabular}


Table 3 Radiocarbon dates for the Bariri Tower profile, BT. For further calculations from BT-40 the mean age of 590 cal. B.P. (cal. A.D. 1370) is taken into consideration as its probability reaches $51 \%$

\begin{tabular}{lcclccc}
\hline Sample & Lab. code & Depth $(\mathrm{cm})$ & Material & Age (B.P.) & Age cal. B.P. (mean, 2 $\sigma$ range) & Age cal. A.D./B.C. (mean, 2 $\sigma$ range) \\
\hline BT-40 & Poz-24158 & $39-40$ & Bulk & $710 \pm 30$ & $585(560-609 ; 51 \%)$ & A.D. 1366 (1341-1390) \\
& & & & $648(625-670 ; 49 \%)$ & A.D. 1298 $(1280-1315)$ \\
BT-88 & KIA39908 & $87-88$ & Bulk & $1931 \pm 35$ & $1804(1714-1893)$ & A.D. 147 (57-236) \\
BT-116 & Erl-11303 & $116-117$ & Bulk & $8550 \pm 69$ & $9479(9395-9562)$ & 7530 B.C. $(7613-7446)$ \\
\hline
\end{tabular}

by applying linear interpolation based on two radiocarbon dates of the upper core section and the modern date of 2006 for the uppermost layer.

\section{Pollen results}

The pollen diagram for BT shows percentages of the terrestrial plant pollen sum for the main pollen and spore types (Fig. 3). Pollen concentrations of the core sampling units range between 17,000 and $1,000,000$ grains $/ \mathrm{ml}$. The pollen diagram is divided into three main pollen assemblage zones, BT $1-3$, and covers a core depth from 103 to $0 \mathrm{~cm}$ as this part contained sufficient pollen grains for counting.

The basal pollen zone, BT-1, 103-90 cm; 4 subsamples; $\sim 5910-2470$ cal. B.P.; sedimentation accumulation rate (SAR) $0.004 \mathrm{~cm} /$ year, comprises pollen of mountain rainforest with tree and shrub values up to $76 \%$. Pollen from Fagaceae, mainly Castanopsis and Lithocarpus, is abundant at 52-65\%. Further pollen of tree taxa originates from Euphorbiaceae such as Macaranga and Acalypha, Myrica type, Melastomataceae, Myrtaceae and Ilex. Pollen transported a long distance from the upper mountain forests is indicated by regular but low values of Phyllocladus, Podocarpus and Dacrycarpus $(<2 \%)$. Pollen from Poaceae and Cyperaceae is present at low values. The spores from Davallia and Pteris belong to ferns in the understory of the mountain rainforest. Charred particles are rare in this zone.

The pollen assemblages of the following zone, BT-2, 90-27 cm; 12 subsamples; $\sim 2470-380$ cal. B.P.; SAR 0.03 $\mathrm{cm} /$ year, are characterised by low values of tree and shrub pollen $(<20 \%)$ and high values of non arboreal pollen ( $\sim 80 \%)$, the latter being dominated by Poaceae. Slight changes in the pollen assemblages allow division of this zone into three subzones.

Arboreal pollen $(\sim 20 \%)$ in Subzone BT 2a $(90-68 \mathrm{~cm})$ is continuously represented by Castanopsis type, Euphorbiaceae, Myrica type (all with decreasing values), Phyllocladus and Podocarpus; Trema and palms temporarily gain in importance. New arboreal taxa occur, such as Melastomataceae and single grains of Elaeocarpaceae and Mora-I Urticaceae. Other pollen of arboreal taxa is absent, such as Mallotus, Grewia, Myrtaceae and Ilex. Poaceae values increase to $65 \%$, but the decrease of the Poaceae pollen at
$71 \mathrm{~cm}$ core depth correlates with the high number of indeterminate pollen grains. Cyperaceae pollen reaches $14 \%$, Asteraceae occur regularly. Spores of Lycopodium cernuum rise to a maximum of almost $60 \%$. The values of Davallia spores decrease while Pteris disappears. The presence of moss spores from Phaeoceros indicates open soils. Charred particles are very frequent (up to 17,604,400 particles $>10 \mu \mathrm{m} / \mathrm{ml}$ ).

The pollen assemblages of Subzone BT $2 \mathrm{~b}(68-50 \mathrm{~cm})$ again show low tree values $(<16 \%)$. While Castanopsis type reaches slightly higher values than in BT 2a, Phyllocladus, Podocarpus, Euphorbiaceae (Macaranga, Acalypha and others) and Melastomataceae continue at the same level. Pollen of Trema is still present. A single pollen grain of Dacrycarpus occurs and a continuous curve of palm pollen starts. Poaceae dominate the non arboreal pollen with up to $70 \%$, Cyperaceae values decrease to $<5 \%$. Asteraceae are present and the new taxon Lamiaceae occurs. Lycopodium cernuum values decrease $(<15 \%)$, Davallia and Phaeoceros remain present. In particular, the start of the pollen curve from aquatic plants such as Myriophyllum allows separation of this subzone. The number of charred fragments shows a severe reduction.

Tree pollen values $(8-18 \%)$ remain low in Subzone BT 2c $(50-27 \mathrm{~cm})$ and are dominated by Castanopsis type. Gymnosperms are still present. Acalypha, Euphorbiaceae p.p., Myrica type, Melastomataceae and palms supplement the arboreal spectra together with the new taxa Celtis, Acanthaceae and Rubiaceae, whereas pollen of Trema disappears. Among the Poaceae pollen a noteworthy increase of Poaceae $>37 \mu \mathrm{m}$ occurs. Asteraceae and Lamiaceae are still present. Spores of Lycopodium cernuum decrease. Spores of Phaeoceros disappear while Davallia and pollen of aquatic plants remain present, although Myriophyllum disappears. Charred particles are frequent (up to $11,110,000$ particles $>10 \mu \mathrm{m} / \mathrm{ml}$ ).

The uppermost pollen zone, BT $3,27-0 \mathrm{~cm} ; 5$ subsamples; $\sim 380$ to -56 cal. B.P.; SAR $0.16 \mathrm{~cm} /$ year, is divided into two subzones. In the pollen assemblages of Subzone BT 3a $(27-7.5 \mathrm{~cm})$, Castanopsis type, Myrica type and palms reach slightly higher values than in the previous zone. Macaranga, Myrtaceae and Mora-/Urticaceae occur again. Pollen of gymnosperms and Melastomataceae remains present. Poaceae $<37 \mu \mathrm{m}$ still 


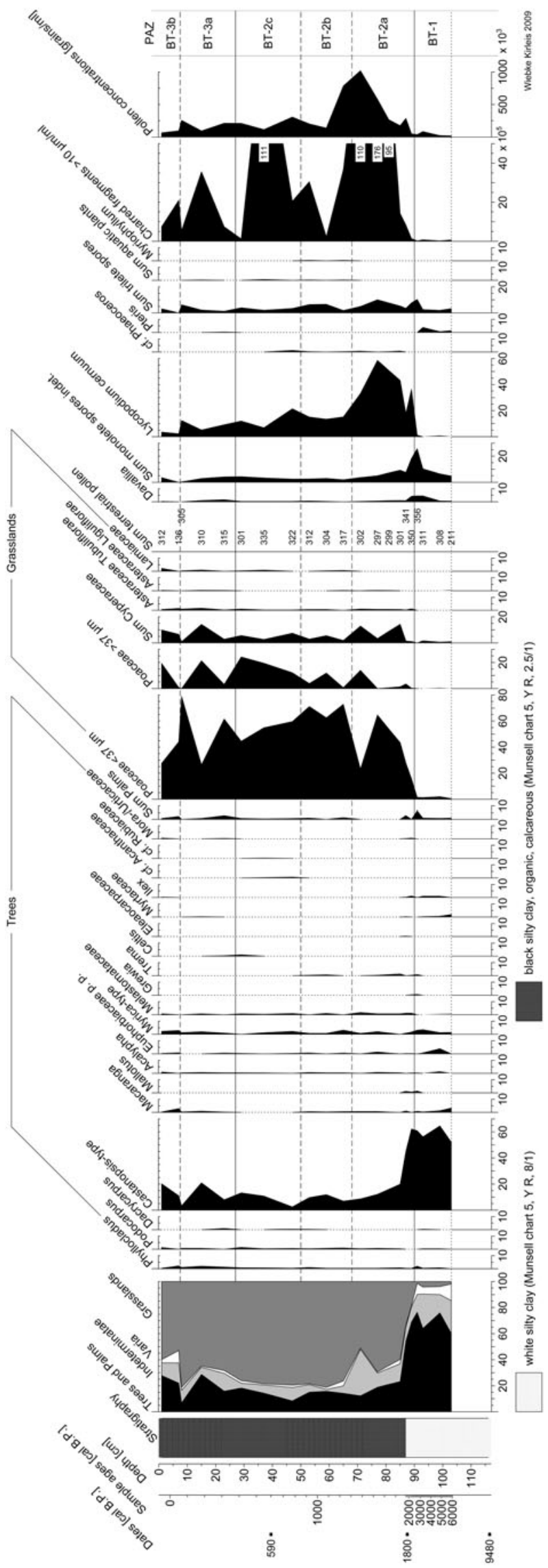

4 Fig. 3 Pollen profile from Bariri Tower (\%), BT, 1,331 m a.s.l., S $01^{\circ} 39.247^{\prime}$, E $120^{\circ} 11.364^{\prime}$

dominate the pollen assemblages of this zone though the representation decreases. Asteraceae reach slightly higher values and Lamiaceae are continuously represented. The values of Davallia rise slightly, Lycopodium cernuum values average $\sim 10 \%$ and Pteris recurs. Aquatic plant pollen is still present. Numerous charred fragments occur.

The uppermost subzone, BT 3b, shows an increase in tree pollen $(>20 \%)$ due to Phyllocladus, Castanopsis type, Macaranga, Acalypha, Euphorbiaceae p.p., Myrica type, Melastomataceae, Mora-/Urticaceae, palms and Ilex. Pollen of small Poaceae decreases $(<40 \%)$ and Poaceae $>37 \mu \mathrm{m}$ increases (up to $19 \%$ ). Non-arboreal pollen is represented by Cyperaceae $(<10 \%)$, low values of Asteraceae and Lamiaceae. Davallia and Lycopodium cernuum spores reach their lowest values of the whole record, while Pteris spores and aquatic plant pollen disappear. The number of charred fragments decreases.

\section{Results of multivariate data analysis applied to the pollen data of the profile BT}

The ordination diagrams show the complete course of vegetation change that spans the period from 5910 to -56 cal. B.P. (with $-56=$ A.D. 2006 ) and indicates a highly directional vegetation dynamic (Fig. 4). Both scatter diagrams resulted from the same ordination analysis; the one on the left plots the subsamples connected over time and the one on the right the pollen taxa. The first and second ordination axes contain respectively $58 \%$ and $17 \%$ of the total variation in the dataset. Both diagrams interpreted together illustrate the change in vegetation types over time. Axis 1 is significant in bootstrap resampling $(\mathrm{P}=0.121)$ and describes a gradient from dense rainforest in the past to open grassland vegetation. The three circles indicate characteristic groups of pollen taxa that occur for each phase of the process. The main (first) ordination axis indicates a distinct trend from predominantly montane forest taxa (Castanopsis type, Fagaceae p.p., Myrtaceae, Ilex, Macaranga, Euphorbiaceae p.p.) on the left to grassland taxa on the right (Poaceae, Asteraceae Tubuliflorae, Cyperaceae). Taxa from the upper montane forest (Podocarpus, Phyllocladus, Dacrycarpus) are plotted in between these two groups as their pollen is present throughout the entire pollen record. The change from rainforest to open grassland vegetation took place between ca. 3260 and ca. 1740 cal. B.P. After the first expansion of the grasslands the process appears to have been essentially random, and after 310 cal. B.P. it changed back towards forest pollen composition. 

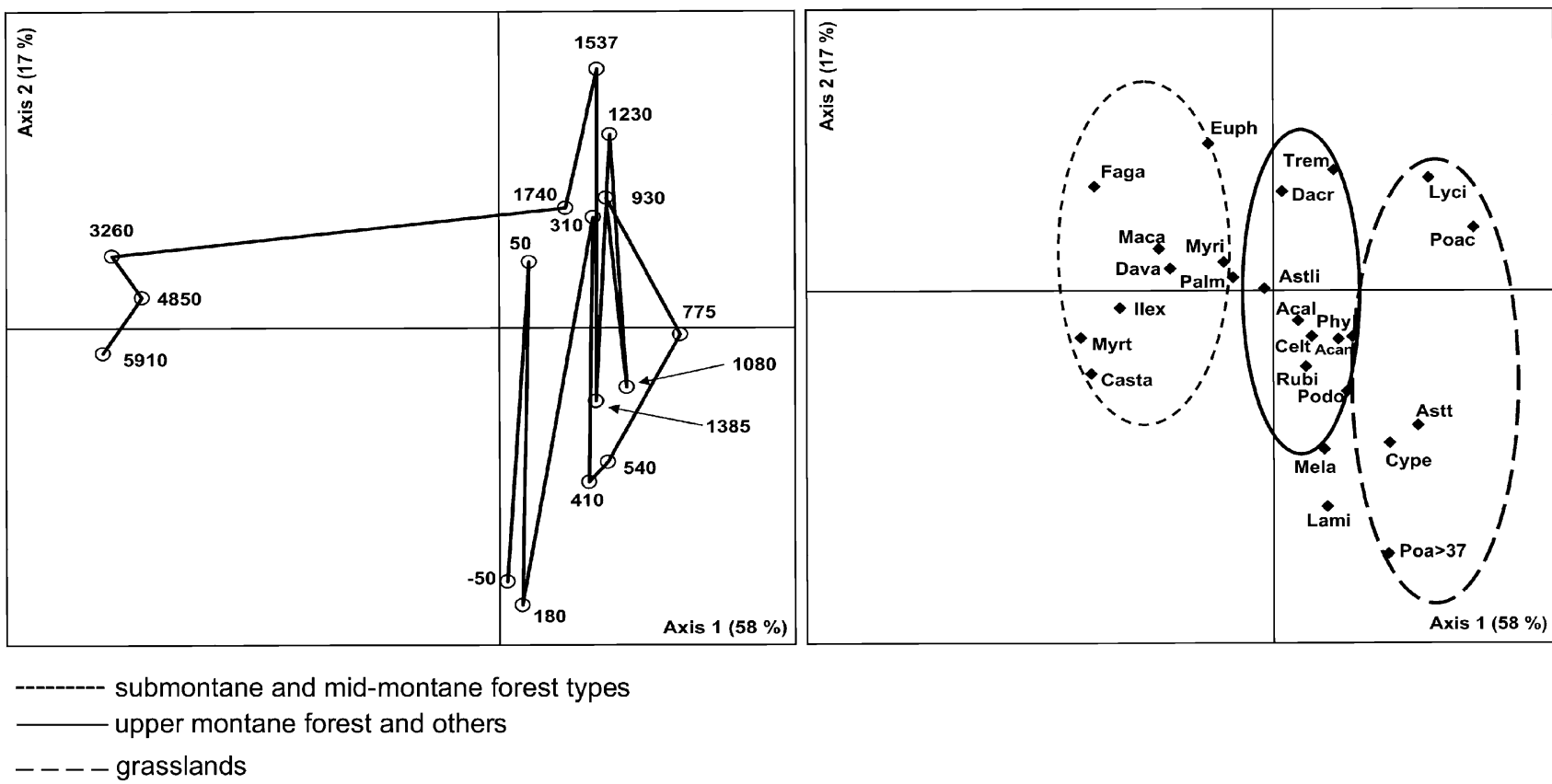

Fig. 4 Ordination diagrams of pollen taxa described from the sediment core from Bariri Tower, BT, diagram on the left with calibrated radiocarbon dates B.P. Taxa abbreviations: Phyl Phyllocladus, Podo Podocarpus, Dacry Dacrycarpus, Casta Castanopsis type, Faga Fagaceae p. p., Maca Macaranga, Acal Acalypha, Acan Acanthaceae, Euphorbiaceae p. p., Myri Myristicaceae, Mela

Melastomataceae, Trem Trema, Celt Celtis, Myrt Myrtaceae, Ilex Ilex, ubi Rubiaceae, Palm Palmae, Poac Poaceae $<37 \mu \mathrm{m}$, Poa $>37$ large Poaceae/cereals, Cype Cyperaceae, Astt Asteraceae Tubuliflorae, Astli Asteraceae Liguliflorae, Lami Lamiaceae, Dava Davallia, Lyci Lycopodium cernuum

Table 4 Stratigraphy of the Pokekea profile, POK. Munsell soil color chart 10, YR, 2/1

\begin{tabular}{lll}
\hline $\begin{array}{l}\text { Depth } \\
(\mathrm{cm})\end{array}$ & Facies & Macro remains \\
\hline
\end{tabular}

$(\mathrm{cm})$

0-45 Poorly decomposed peat, root zone

46-99 Decomposed peat with mica

100-112 Limnic, peaty, with mica

113-122 Limnic, peaty, with mica

123-131 Limnic, silty, with mica and fine grain sand

132-134 Limnic, sand, mica

135-150 Limnic, mica, fine grain sand

151-174 Limnic, organic, mica

175-250 Organic enriched clay, mica

251-309 Limnic clay, sand, mica

310-328 Limnic clay, sand, mica
Charred grass fragments, fine roots, fragments of plant tissues, fruits of Poaceae and Cyperaceae, indeterminable seeds, insect remains

Fine roots, fragments of plant tissues, indeterminable seeds, charred fragments, insect remains

Oogonia of Characeae, seeds of Juncus, fine roots, coarse fragments of plant tissues, charred fragments, indeterminable seeds, insect remains

Seeds of Juncus, fruits of Asteraceae, fine roots, fragments of plant tissues, charred fragments of Poaceae, indeterminable seeds, insect remains

Seeds of Juncus, indeterminable seeds, coarse fragments of plant tissues, charred fragments of Poaceae, insect remains (fine roots)

Oogonia of Characeae, some fragments of plant tissues, indeterminable seeds, charred fragments of Poaceae

Seeds of Juncus, indeterminable seeds, fragments of plant tissues, charred fragments of Poaceae, fruits of Asteraceae and Cyperaceae (fine roots)

Oogonia of Characeae $(160-168 \mathrm{~cm})$, charred grass fragments, fragments of plant tissues, indeterminable seeds, wood, insect remains (fine roots)

Fine roots, charred fragments, seeds and fruits of Rosaceae (Rubus sp.), Poaceae and Cyperaceae, indeterminable seeds, fragments of plant tissues

Charred grass fragments, Oogonia of Characeae, seeds and fruits of Juncus sp., Rosaceae, Poaceae and Cyperaceae, fragments of plant tissues, fine roots, seeds of indeterminable seeds, insect remains, wood, Daphnia eggs (ephippia)

Oogonia of Characeae, fine roots, fragments of plant tissues, fruits of Cyperaceae, insect remains, wood 


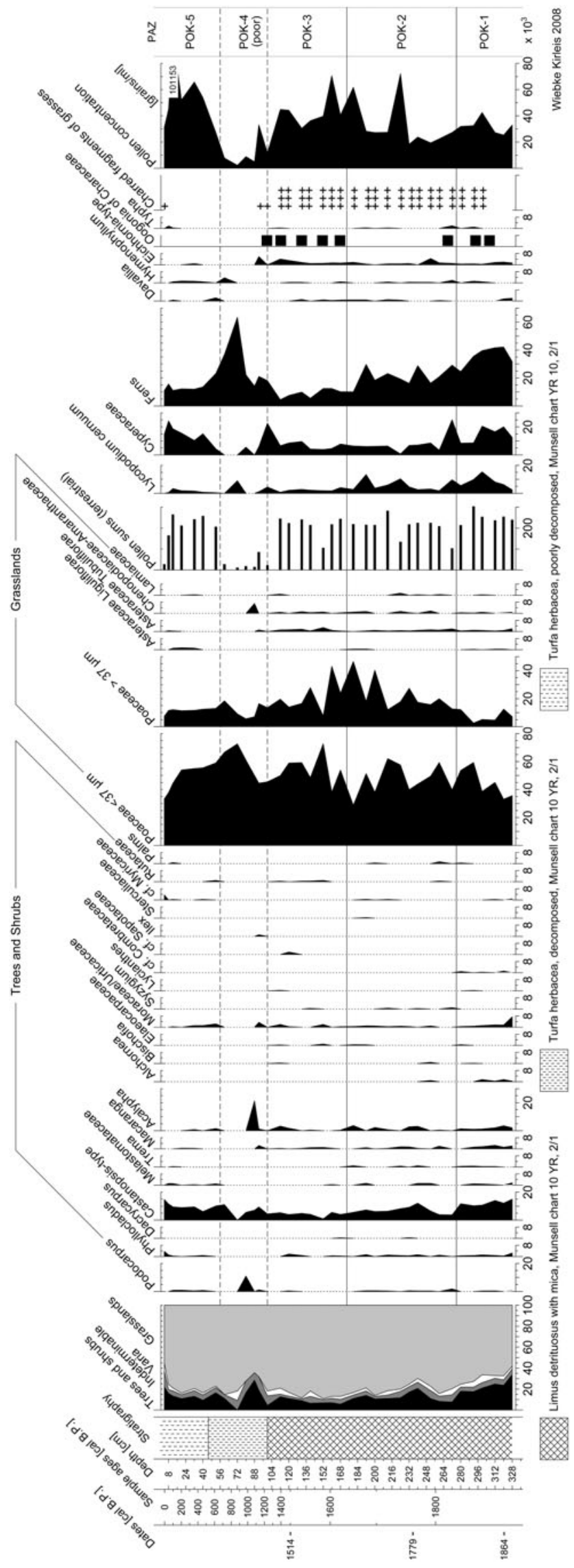

4 Fig. 5 Pollen profile from Pokekea (\%), POK, 1,213 m a.s.l., $\mathrm{S} 01^{\circ} 41.530^{\prime}, \mathrm{E} 120^{\circ} 12.758^{\prime}$

Pollen profile Pokekea, POK

\section{Sedimentology, local vegetation development and chronology}

The profile consists of two main units. The underlying silty clay is replaced by peat at $100 \mathrm{~cm}$ depth. Depending on the content of different macro remains, 11 subunits that describe the local vegetation at the coring site are distinguished (Table 4). Oogonia of Characeae and Daphnia eggs prove that the sediment growth of the profile POK started under limnic conditions. The pollen curve of Monochoria (Eichornia type) indicates a high water level for the entire section $328-100 \mathrm{~cm}$, supported by the repeated occurrence of oogonia of Characeae. Seeds of Juncus sp. show the swampy catchment area of the river channels. No charcoal was found in the basal part of the profile $(328-310 \mathrm{~cm})$. The largest amounts of charred fragments continuously occur at $310-90 \mathrm{~cm}$ core depth. Pollen concentrations decrease to nil at a depth of $100-56 \mathrm{~cm}$ (1240-670 cal. B.P.). The peat of this unit mainly consisted of fine roots and coarse plant tissues. Supply of oxygen has led to decomposition of the fine organic matter like pollen grains. The uppermost section of the profile consisted of peat with wet anoxic conditions, as pollen grains have survived in this material. Surprisingly, the section with low pollen concentration (Fig. 5) is not consistent with the boundaries suggested by changes in occurrence of particular macro remains.

The results of radiocarbon dating are shown in Table 5. Subsample ages were calculated with TILIA by applying linear interpolation based on three radiocarbon dates and the modern date of 2006 for the uppermost layer (Grimm 1990). The age of the oldest sediment layer of this core is about 1860 cal. B.P.

\section{Pollen results}

The pollen diagram Pokekea, POK, consists of 36 subsamples (Fig. 5). Pollen concentrations range between 2,300 and 101,000 grains $/ \mathrm{ml}$. The pollen diagram is divided into five main pollen zones, POK 1-5. In Zone POK 4, pollen percentages could not be calculated due to very low pollen concentrations. Throughout the whole record the pollen assemblages are dominated by the non arboreal taxa Poaceae, Cyperaceae and ferns.

In the lowest part of the record in Zone POK 1, 328-276 cm; six subsamples; $\sim 1870-1820$ cal. B.P., SAR $1.0 \mathrm{~cm} /$ year, tree and shrub pollen reaches its highest values of the 
Table 5 Radiocarbon dates for the Pokekea profile, POK, and the adjacent archaeological site Pokekea (sediment cores from stone vats no. 27 and 74)

\begin{tabular}{llllllc}
\hline Sample & Lab. code & Depth $(\mathrm{cm})$ & Material & Age (B.P.) & cal. B.P. (mean; 2 $\sigma$ range) & cal. A.D. (mean; 2 $\sigma$ range) \\
\hline POK-122 & Erl-10580 & $121-122$ & Bulk & $1692 \pm 33$ & $1510(1413-1615)$ & $440(335-537)$ \\
POK-236 & Erl-10581 & $235-236$ & Bulk & $1879 \pm 33$ & $1780(1692-1866)$ & $170(84-258)$ \\
POK-321 & Erl-10582 & $320-321$ & Wood & $1979 \pm 31$ & $1860(1777-1950)$ & $90(-1-173)$ \\
Vat no. 74 & Erl-10584 & 23 & Seed & $1251 \pm 31$ & $1120(1052-1184)$ & $830(766-898)$ \\
& Erl-10585 & $43-44$ & Bulk & $1197 \pm 30$ & $1050(968-1141)$ & $900(809-982)$ \\
Vat no. 27 & Erl-11305 & $32-33$ & Bulk & $949 \pm 45$ & $740(678-804)$ & $1120(1033-1215)$ \\
& Erl-11306 & $45-46$ & Bulk & $890 \pm 39$ & $830(735-917)$ & $1210(1146-1272)$ \\
\hline
\end{tabular}

entire record with an average of 34\%. This pollen is mainly from Castanopsis type, Melastomataceae, Euphorbiaceae like Macaranga, Acalypha or Alchornea, Moraceae/Urticaceae and Trema. Long distance pollen which had come from the upper montane forest is indicated by Phyllocladus (0.4-2.5\%) and single grains of Podocarpus. Poaceae show a marked increase from 35 to $54 \%$ in this zone. Low values of Poaceae $>37 \mu \mathrm{m}$ hint at rice cultivation. The Cyperaceae curve is the reverse of the Poaceae curve, decreasing from high values in the lower part of POK 1 to low values at the boundary with POK 2 . Fern spores have high values. An increase of Lycopodium cernuum together with charred fragments was observed simultaneously with the decline of the tree and shrub values.

The lower boundary of Zone POK 2, 276-174 cm; 10 subsamples; 1820-1630 cal. B.P.; SAR $0.6 \mathrm{~cm} /$ year, is marked by a decrease of Castanopsis type. Syzygium and Rutaceae pollen occur for the first time. Pollen of Trema is still present. Most important, Euphorbiaceae pollen is from Acalypha and Macaranga. Pollen of Podocarpus and Phyllocladus is continuous, and single grains of Dacrycarpus occur. The pollen assemblages are characterised by high Poaceae values. The oscillations of the curve of Poaceae $>37 \mu \mathrm{m}$ most probably are a result of poor pollen preservation, as a large number of folded and crumpled pollen grains was recorded for this zone. Cyperaceae values range between 4 and 9\%. Spores of Lycopodium cernuum are slightly less represented (5\%).

The pollen composition of Zone POK 3 resembles that of Zone POK 2. In Zone POK 3, 174-100 cm; seven subsamples; $\sim 1630-1260$ cal. B.P.; SAR $<0.5 \mathrm{~cm} /$ year, tree and shrub pollen is low, whereas Poaceae pollen is frequent. The tree and shrub sum mainly consists of Moraceae/Urticaceae, Macaranga, Acalypha and Rutaceae. Single grains of Elaeocarpaceae, Syzygium, Lycianthes and cf. Sapotaceae occur. Trema pollen is absent. The Podocarpaceae values decrease. Poaceae pollen dominates the assemblages in this section. Cyperaceae values remain at their former level whereas the values of fern spores decrease. Asteraceae Tubuliflorae show slightly higher values. Spores of Lycopodium cernuum decrease.

The pollen content of Zone POK 4, 100-56 cm; six subsamples; 1260-710 cal. B.P., is very low. Pollen counts ranged between 11 and 85 grains and did not allow for further counting. The stratigraphy in this section changes from limnic facies towards peat. From the macro remains, the upper part of this zone does not show a distinct border with POK 5 (Table 4).

The uppermost zone, POK 5, 56-0 cm; seven subsamples; $\sim 710$ to -56 cal. B.P.; SAR $0.08 \mathrm{~cm} /$ year, shows a marginal increase in tree and shrub pollen, namely from Castanopsis type. Melastomataceae and cf. Myricaceae become common. Macaranga and Acalypha pollen is present. A single pollen grain of Rutaceae and pollen of Trema occurs. As in Zone POK 2, the Podocarpaceae curves are continuous. Poaceae pollen values decrease while Cyperaceae increase. In contrast to the preceding zone, Asteraceae Liguliflorae gains importance, but Asteraceae Tubuliflorae is hardly represented. The curve of Lycopodium cernuum spores is continuous.

\section{Discussion}

Vegetation history of the Besoa valley

Pollen analysis of the sediment core from BT illustrates the vegetation history of the last 6,500 years there. The pollen assemblages display widespread undisturbed montane rainforest for a time span lasting until ca. 2000 cal. B.P. (PAZ BT 1). Fagaceae, Myrtaceae, Melastomataceae, Myricaceae and Ilex characterise the submontane to midmontane plant communities. Influence of lower montane trees is indicated by Euphorbiaceae and Moraceae/Urticaceae. Modern tree records on plot sites within the Lore Lindu area show that Podocarpaceae reach their highest above ground biomass at an altitude of 2,400 $\mathrm{m}$ (Culmsee et al. 2010), so in the pollen record they represent upper 
montane forests. Natural fires hardly affected the forest composition, as indicated by low numbers of charred particles. A distinct change of sediment colour from light brown to black at $87 \mathrm{~cm}$ core depth reflects the high influx of charred particles into the upper core section. It is consistent with an abrupt vegetation change from montane forest to grassland which took place at this level around ca. 2000 cal. B.P. Since that time, widespread grasslands have characterised the Besoa valley. Periodic burning of the grasslands has since prevented any forest from recovering in the valley until modern times. The origin of the Besoa valley grasslands from human activity has not previously been known.

The correlation of high Lycopodiaceae values with forest disturbance (Stuijts 1993) can now be specified. In central Sulawesi, the spread of grasslands was an impetus for an initial expansion, particularly of Lycopodium cernuum. Only small patches of montane forest remained in the valley as the light demanding secondary forest taxon Trema temporarily occurred after the clearance had started (BT 2). The occurrence of Rubiaceae in BT 2c may be related to human impact, since many useful trees belong to this family and may indicate the existence of gardens (Kehlenbeck 2007). The steady input of gymnosperm pollen from the upper montane forest throughout the whole record shows that steep mountain areas were presumably less affected by fire. A minor increase in montane forest taxa is detected in the uppermost core section. However, it is questionable whether this is a response to nature conservation action. It may just reflect the settlement and land use abandonment in the late 20th century close to the coring location, which was indicated in interviews with local people.

Multivariate analyses of the pollen data reveal the complex dynamics of the rainforest vegetation system. A phase of directional vegetation change from stable rainforest conditions towards spreading of grasslands is followed by a unidirectional chaotic phase and then a slight change back to forest conditions. Slash and burn in particular has caused rapid vegetation changes.

The sediment core at Pokekea, POK, provides a history of the floodplain of the meandering rivers Lumamba and Lengi where sediment growth started under limnic conditions. The vegetation has been dominated by grasslands for the last 2,000 years. Rainforest taxa are restricted to about $20 \%$ of the terrestrial pollen sum. Slightly larger numbers of montane forest taxa occur only at the base of the core. Rice was possibly cultivated, since large pollen grains of Poaceae and rice weeds were present throughout. The pollen assemblages resemble those of the BT profile because they come from the same valley. However, Moraceae/Urticaceae pollen indicates disturbance and hence continuing human activity. Of particular interest for reconstructing landscape changes is the zone of low pollen concentrations, POK 4. Oxidation has led to decomposition of the organic sediment content so that the pollen concentration decreases to zero. This section of poor pollen preservation can probably be interpreted as the result of variation in the hydrology, so that the sediment changed from lacustrine to peaty as the area around the rivers became dry. Lasting from A.D. 710 to 1280 (= $1240-670$ cal. в.P.; $100-56 \mathrm{~cm}$ ), the hydrological change may have been caused by either drought or human impact. In the Indonesian archipelago, climate is affected by the sea surface temperatures (SST) in the western Pacific warm pool (WPWP). The latter is part of the Indo-Pacific warm pool and influences the dynamics of the El Niño Southern Oscillation (ENSO) and the east Asian monsoon (Linsley et al. 2010; Oppo et al. 2009). ENSO drought events may have caused environmental change in central Sulawesi. Long lasting naturally occurring peat fires, as in Kalimantan, Borneo, in 1997/1998, can be excluded for Sulawesi as there are no comparable large peat deposits there (Page et al. 2002). For east Java, there is evidence for a drought period lasting from ca. A.D. 1275-1325, from geochemical analyses at the bottom of a laminated sediment core (Crausbay et al. 2006). However, this drought period may not necessarily have affected Sulawesi because of micro-regional differences. Furthermore, the dating is slightly too late compared to the Pokekea record, and older material was not available from the Java sediment core. A 400 year long period with warm temperatures and high salinities starting around A.D. 1000 that is equivalent to the northern Hemisphere medieval warm period (MWP) has to be considered, if data from investigations of the marine core MD9821-60 in the Makassar Strait is considered (Newton et al. 2006). Here the warmest SST and highest salinities are interpreted from $\mathrm{Mg} / \mathrm{Ca}$ and $\delta^{18} \mathrm{O}$ measurements of planktonic foraminifera. The observations show similar conditions if compared to the present day. This evidence is supported by measurements of $\delta^{15} \mathrm{~N}$ ratios from the marine core BJ8-03-102GGC from Kau Bay, Halmahera, where a basin stagnation was observed during the time of the MWP ( $\sim 1000-750$ yr в.P.) that indicates less ENSO-like conditions (Langton et al. 2008). However, there is still no direct evidence for drivers of the hydrological change in the catchment of the rivers Lengi and Lumamba in the Besoa valley around 1000 B.P. Human impact can be taken into account as well: new radiocarbon dating applied to sediments from the interior of large stone vats provides a terminus ante quem for the adjacent archaeological site of Pokekea. The dating to $\sim 1000 \mathrm{cal}$. B.P. (Table 5) shows that human activity at the site, possibly the erection of the monuments, coincides with the hydrological changes in the floodplain. Possibly, the people at the Pokekea site have shaped their landscape not only by raising stone sculptures and stone jars but furthermore by changing its natural components, the courses of the rivers Lengi and 
Lumamba. Obviously, there is need for future investigations to decide whether human-induced change of the river course or drought has to be taken into consideration as the main origin of the hydrological change in the Besoa valley.

The change back to good pollen preservation at a depth of $56 \mathrm{~cm}$ (POK 5) may be correlated with climate change. A general cooling trend beginning around A.D. 1400 is again indicated for the macro-region by the investigations of foraminifera of the Makassar Strait marine core MD982160 (Newton et al. 2006). It lasted for several hundred years and provided more precipitation south of the equator during the period of the Little Ice Age (LIA, ca. A.D. 1400-1850). This is in contrast to observations for the (sub-) tropical regions north of the equator, where increased aridity is indicated during the LIA (Haug et al. 2001; Wang et al. 1999; Watanabe et al. 2001). The contrasting latitudinal precipitation/aridity pattern is interpreted as being indicative of a pronounced and rapid southwards displacement of the Inter-tropical Convergence Zone (ITCZ) (Newton et al. 2006). The peat growth at the coring location at Pokekea shows a hydrological change towards wetter conditions which may be linked to increased precipitation south of the equator during the LIA.

\section{First forest clearance in the Lore Lindu area}

Human activity appears to have been the main cause of ecosystem change in the Holocene. However, it remains difficult to exclude the possibility that the climate change related to El Niño, which may also have played a role in past vegetation dynamics of New Guinea according to Haberle (2007), may also apply to central Sulawesi. However, signs of human impact in pollen records often overlay climate signals, especially in the tropics. Thus, it is only possible to trace evidence of past climatic changes and El Niño events if at least an elementary knowledge of (pre-) history exists. In central Sulawesi it is our palaeoecological data on past human activity that serves as a background for future research to separate natural from human influences in past environmental change.

Allocating micro-regions is important to describe past interactions between humans and the environment. Two pollen records from the Besoa valley together with numerous archaeological sites (Kaudern 1938; Whitten et al. 1987) reveal a long tradition of human activity in the south of the national park. An abrupt rise in charred particles coincides with the beginning of the spread of grasslands (Fig. 3). Thus, the history of forest clearance is much older than archaeologists have expected from the lack of finds of stone adzes and axes. The theory that forest clearance began about 1,500 years ago when iron was introduced (Whitten et al. 1987), has to be abandoned.
Microfossil analysis shows that people were able to open impenetrable rainforest from about $2000 \mathrm{cal}$. B.P.

In contrast to the developments in the south of the park, the existence of undisturbed closed canopy lowland rainforest is indicated for almost all of the last 1,000 years through a palaeo-record in sediments from lake Lindu, situated $25 \mathrm{~km}$ further to the north at $1,000 \mathrm{~m}$ a.s.l. Only the pollen assemblages from the uppermost core section show human presence in modern times. The same is true for the upper montane forest surrounding lake Kalimpaa at $1,700 \mathrm{~m}$ a.s.l. (Cook et al. 2008; E. Cook, personal communication). Variations in rainfall can be excluded to explain the different developments as is shown in climate diagrams for two localities in the Lore Lindu National Park at 1,400 and 1,800 m a.s.l. (Culmsee et al. 2008, p 18). However, the altitudinal gradient shows a slight temperature range that probably led to regional differences in past vegetation dynamics at lake Kalimpaa compared to the Besoa valley. Modern forest composition in the area shows a trend of decreasing above ground biomass estimates with increasing altitude, if Fagaceae are excluded. Together, a decrease in taxon richness is observed with increasing elevation, but mainly towards upper montane forests above 2,400 $\mathrm{m}$ a.s.l., and has to be considered when the vegetation history around lake Kalimpaa at $1,700 \mathrm{~m}$ a.s.l. is checked against that of the Besoa valley at 1,200-1,400 m a.s.l. (Culmsee et al. 2010). However, the main reason for the contradictory environmental histories of the Besoa valley, lake Lindu and lake Kalimpaa, which are situated a short direct distance from each other, is the fact that there was probably a mosaic of settlement clusters and untouched rainforest areas during prehistoric times. Lakes Lindu and Kalimpaa are situated in a remote area, far away from prehistoric communication routes. Rapid widespread impacts such as a "Neolithic transition" or climate change do not account for the observed regional differences. This is also the case in New Guinea (Haberle 2007), where the prehistoric grassland expansion varies in date and extent to a considerable degree. In the Baliem valley, human activity and forest clearance had started as early as $7000 \mathrm{cal}$. B.P. and was associated with continuous burning after 3000 B.P., when extensive grasslands were established (Haberle et al. 1991). In the Iftaman valley there is evidence of transient forest clearance as early as 11500 and 8500 B.P., where primary forest was re-established after a phase of abandonment and lasted for some 4,000 years; there the grassland expansion started around 4500 B.P. when forest was cleared from the site (Hope 1983). The (pre-) history of forest clearance and the spread of agriculture in central Sulawesi as well as in New Guinea have to be analysed on a micro-regional scale and will result in the development of a complex model of landscape history (Haberle 2007). 
Detecting early agriculture in central Sulawesi

Human activity has played an important role in modifying rainforest vegetation systems. Changes of the forest composition were often influenced by the spread of agriculture, which in southeast Asia is linked to rice cultivation. However, evidence for rice cultivation is difficult to detect by pollen analysis (Maloney 1990) and ideally has to be supported by macrofossil and phytolith studies. The pollen grains of Oryza sativa measure between 36.3 and $48.0 \mu \mathrm{m}$ in diameter and are difficult to distinguish from wild Poaceae pollen grains (Beug 2004). Maloney (1990) lists measurements of different varieties with even smaller diameters. Therefore, tracing human influence in pollen records has to concentrate on indirect, secondary evidence for agricultural activity. As well as pollen types of secondary forest taxa, garden weeds and grassland plants, the influx of charred particles serves as an indicator of anthropogenic influence (Haberle 1994).

For the Besoa valley, large Poaceae pollen grains ( $>37 \mu \mathrm{m}$ in diameter) accompanied by the rice weeds Monochoria (Eichhornia type) and Cyperaceae (Naples and Keßler 2005), large numbers of charred fragments and a decrease of arboreal pollen are taken into consideration to indicate forest opening and hint at rice cultivation. Macro-remain studies on soil samples from archaeological excavations give evidence for weedy grasses and sedges that accompany early rice agriculture in southeastern Asia (Ahn 2010; Fuller et al. 2009; Weber et al. 2010; Zhao 2010). In India, beside Poaceae and Cyperaceae, some Polygonaceae, Convolvulaceae and Commelinaceae are listed as weeds of wet rice cultivation (Fuller and Qin 2009, p 104). Monochoria, which is a common weed genus in modern paddy culture for example, in Japan (Yamasue and Ueki 1983), is only distinguishable in pollen records. In the remote central Sulawesi Besoa valley, areas under cultivation were probably established at latest around 1870 cal. B.P. (Fig. 5). This assumption is consistent with the date for the arrival of the Neolithic transition and agriculture in Sulawesi between 4500 and 3300 в.P. (Bellwood 2007b).

Future archaeobotanical research on macrofossils from archaeological sites will help clarify the first appearance of rice cultivation in central Sulawesi.

\section{Conclusions and outlook}

The environmental history and the archaeological remains show evidence of long-term human impact on central Sulawesi. However, it is shown that vegetation changes in the region have been caused by human activity as well as by climate change. Three main points can be concluded from our palaeo-records:
1) The first forest clearance occurred about 2,000 years ago in the remote area of the Besoa valley.

2) Paddy culture is indicated for the time span from ca. 1900 cal. B.P. up to modern times.

3) The temporary occurrence of a hydrological change in the Besoa valley matches a) human activity in the vicinity of the site and b) correlates with a general cooling trend observed in the macro-region for the beginning of the Little Ice Age (LIA) ca. A.D. 1400.

Investigations in central Sulawesi show that long-term ecological studies can provide a scientifically defensible basis for conservation management (Willis et al. 2004). They show, for example, where primary rainforest in an untouched state still exists or to what extent humans have shaped the taxon composition in (post-) rainforest habitats. The widespread grasslands that nowadays characterise the Besoa valley have been influenced by humans over the last 2,000 years; before this, undisturbed montane forest had existed. In the STORMA project we have found that periodical burning and forest clearance since 2000 cal. B.P. are irreversible if burning continues. However, the change back to forest pollen composition in the uppermost part of the pollen record from BT points to possible succession towards the re-establishment of montane rainforest, if human impact is excluded (Fig. 4). Thus, it becomes feasible to envisage reforestation of grasslands which were close to remaining forests. However, it had been assumed up to now that these grasslands were of natural origin. Thus, the environmental history record can provide recommendations for nature conservation measures which include reforestation of the forest margin grasslands. Considering future climate change, reforestation of the vast unused grassland area would contribute to the stabilisation of the climate and would enlarge the carbon storage potential of the park area. In contrast, for the easily accessible inner Besoa valley the long tradition of land use for about the last 2,000 years should be taken into account. Here, archaeological materials and results of the palaeo-records suggest that the establishment of a buffer zone of the biosphere reserve that would allow for extensive human activity.

Acknowledgments Research was carried out as part of subproject C7 of the Collaborative Research Centre SFB 552 "Stability in Rainforest Margins" (STORMA), at Göttingen University and was funded by DFG, Germany. We gratefully acknowledge logistic support from STORMA's Indonesian partner universities in Bogor and Palu, Institut Pertanian Bogor (IPB) and Universitas Tadulako (UNTAD), the Ministry of Education in Jakarta (DIKTI), the Indonesian Institute of Sciences (LIPI), the authorities of Lore Lindu National Park, our Indonesian counterparts Ir Iskandar (IPB) and Johannis Mogea (Herbarium Bogoriense, Bogor). We are grateful to Mr Iksam, State Museum Central Sulawesi, Palu, Indonesia, for his introduction to the megalithic sites in the Lore Lindu National Park's area. Stefan Erasmi, Göttingen University, provided the basic map of Fig. 1, while Corinna Kortemeier and Ines Reese, Kiel University, assisted with the 
detailed map of the Besoa valley (Fig. 2). We thank Sander van der Kaars, Göttingen University, and Raymond van der Ham, National Herbarium of the Netherlands in Leiden, for advice in pollen morphology. Material for the modern reference collection was collected at the Herbarium Bogoriense, Indonesia, and at the National Herbarium of the Netherlands in Leiden, the latter with support by an EU Synthesis travel grant, NL-TAF-3869. Finally, we would like to thank two anonymous reviewers for useful comments on the manuscript and James Greig for improving the English.

Open Access This article is distributed under the terms of the Creative Commons Attribution Noncommercial License which permits any noncommercial use, distribution, and reproduction in any medium, provided the original author(s) and source are credited.

\section{References}

Ahn S-M (2010) The emergence of rice agriculture in Korea: archaeobotanical perspectives. Archaeol Anthropol Sci 2:89-98

Anshari G, Kershaw AP, van der Kaars S (2001) A late Pleistocene and Holocene pollen and charcoal record from peat swamp forest, Lake Sentarum Wildlife Reserve, West Kalimantan, Indonesia. Palaeogeogr Palaeoclimatol Palaeoecol 171:213-228

Arifin K, Sellato B (2003) Archaeological survey and research in four subdistricts of interior East Kalimantan. In: Eghenter C, Sellato B, Devung GS (eds) Social science research and conservation management in the interior of Borneo. CIFOR, Indonesia, pp 199-239

Bellwood P (2007a) Prehistory of the Indo-Malaysian Archipelago. Australian National University E-Press, Canberra

Bellwood P (2007b) The spread of agriculture into southeast Asia and Oceania. In: Bellwood P (ed) First farmers. The origins of agricultural societies, Malden, pp 128-145

Beug H-J (2004) Leitfaden der Pollenbestimmung für Mitteleuropa und angrenzende Gebiete. Pfeil, München

Cannon CH, Summers M, Harting JR, Keßler PJA (2007) Developing conservation priorities based on forest type, condition and threats in a poorly known ecoregion: Sulawesi, Indonesia. Biotropica 39:747-759

Colani M (1935) Megalithes du Haut-Laos, Hua Pan. Tran Ninh, Paris

Cook E, Haberzettl T, van der Kaars S, Kirleis W (2008) Highresolution, multi-proxy records of palaeoenvironmental change through the last millennium from Lakes Lindu and Kalimpaa, central Sulawesi, Indonesia. In: Grosse et al (eds) Tropical rainforests and agroforests under global change, Proceedings International Symposium (October 5-9, 2008, Kuta, Bali, Indonesia), Universitätsverlag Göttingen, p 104

Crausbay S, Russell J, Schnurrenberger D (2006) A ca. 800-year lithologic record of drought from sub-annually laminated lake sediment, East Java. J Paleolimnol 35:641-659

Culmsee H, Pitopang R (2009) Tree diversity in sub-montane and lower montane primary rain forests in Central Sulawesi. Blumea 54:119-123

Culmsee H, Kirleis W, Moser G, Pitopang R, Erasmi S, Clough Y, Lorenz W (2008) Exploring the tree diversity of primary forests of Lore Lindu National Park (Central Sulawesi), visiting the Sulawesi throughfall displacement experiment plots and Pokekea Megalithic Places. Field guide to the field-trip of the Conference on Tropical Rainforests and Agroforests under Global Change, October 10-15, 2008, Göttingen, SFB 552, STORMA, Göttingen University

Culmsee H, Leuschner C, Moser G, Pitopang R (2010) Forest aboveground biomass along an elevational transect in Sulawesi,
Indonesia, and the role of Fagaceae in tropical montane rain forest. J Biogeogr. doi:10.1111/j.1365-2699.2009.02269.x

Dam RAC, Fluin J, Suparan P, van der Kaars S (2001) Palaeoenvironmental developments in the Lake Tondano area (N. Sulawesi, Indonesia) since 33.000 yr B.P. Palaeogeogr Palaeoclimatol Palaeoecol 171:147-183

Erasmi S, Twele A, Ardiansyah M, Malik A, Kappas M (2004) Mapping deforestation and land cover conversion at the rainforest margin in Central Sulawesi, Indonesia. EARSeL eProc 3:388-397

Fægri K, Kaland P, Krzywinski K (eds) (1989) Textbook of pollen analysis, 4th edn. Wiley, Chichester

Flenley JR (1967) Highland Papua New Guinea pollen flora I. In: Flenley JR (ed) The present and former vegetation of the Wabag resion of New Guinea. Dissertation, Australian National University Canberra (extract at http://palaeoworks.anu.edu.au/data bases.html)

Fuller DQ, Qin L (2009) Water management and labour in the origins and dispersal of Asian rice. World Archaeol 41:88-111

Fuller DQ, Qin L, Zheng Y, Zhao Z, Chen X, Hosoya LA, Sun G-P (2009) The domestication process and domestication rate in rice: spikelet bases from the lower Yangtze. Science 323:1,607-1,610

Garrett-Jones SE (1979) Pollen flora: lowland Papua New Guinea. In: Garrett-Jones SE (ed) Evidence for changes in Holocene vegetation and lake sedimentation in the Markham Valley, Papua New Guinea. Dissertation, Australian National University Canberra (extract at http://palaeoworks.anu.edu.au/databases. html)

Gerold G, Fremery M, Guhardja E (2004) Land use, nature conservation and the stability of rainforest margins in southeast Asia. Springer, Heidelberg

Goeltenboth F, Langenberger G, Widmann P (2006) 18; Mountain forests. In: Goeltenboth F, Timotius KH, Milan PP, Margraf J (eds) Ecology of insular southeast Asia: the Indonesian archipelago. Elsevier, Amsterdam, pp 410-413

Gremmen WHE (1990) Palynological investigations in the Danau Tempe depression, southwest Sulawesi (Celebes), Indonesia. Mod Quat Res Southeast Asia 11:123-134

Grimm E (1990) TILIA and TILIAGRAPH. PC spreadsheet and graphics software for pollen data. INQUA working group on data handling methods. Newsletter 4:5-7

Haberle S (1994) Anthropogenic indicators in pollen diagrams: problems and prospects for late Quaternary palynology in New Guinea. In: Hather JG (ed) Tropical archaeobotany applications and new developments. Routledge, London, pp 172-201

Haberle S (2007) Prehistoric human impact on rainforest biodiversity in highland New Guinea. Philos Trans R Soc B 362:219-228

Haberle S, Hope GS, Defretes Y (1991) Environmental changes in the Baliem valley, montane Irian Jaya, Republic of Indonesia. J Biogeogr 18:25-40

Haug GH, Hughen KA, Sigman DM, Peterson LC, Roehl U (2001) Southwards migration of the intertropical convergence zone through the Holocene. Science 293:1,304-1,308

Hope GS (1983) The vegetational changes of the last 20, 000 years at Telefomin, Papua New Guinea. Singap J Trop Geogr 4:25-33

Hope GS (2001) Environmental change in the Late Pleistocene and later Holocene at Wanda site, Soroako, South Sulawesi, Indonesia. Palaeogeogr Palaeoclimatol Palaeoecol 171:129-145

Huang T-C (1972) Pollen flora of Taiwan. Ching-Hwa Press, Taipei

Kaudern W (1938) Results of the author's expedition to Celebes 1917-20. Megalithic finds in central Celebes, Elanders, Göteborg

Kehlenbeck K (2007) Rural homegardens in central Sulawesi, Indonesia: an example for a sustainable agro-ecosystem? Dissertation, Göttingen University

Keßler PJA, Bos M, Sierra Daza S, Willemse L, Pitopang R, Gradstein S (2002) Checklist of woody plants of Sulawesi, 
Indonesia. Blumea Supplement 14. National Herbarium Nederland, Universiteit Leiden, Leiden

Langton SJ, Linsley BK, Robinson RS, Rosenthal Y, Oppo DW, Eglinton TI, Howe SS, Djajadihardja YS, Syamsudin F (2008) $3500 \mathrm{Yr}$ record of centennial-scale climate variability from the Western Pacific Warm Pool. Geology 36:795-798

Linsley BK, Rosenthal Y, Oppo DW (2010) Holocene evolution of the Indonesian throughflow and the western Pacific warm pool. Nat Geosci 3:578-583

Maloney BK (1990) Grass pollen and the origins of rice agriculture in North Sumatra. Mod Quat Res Southeast Asia 11:135-161

McCormac FG, Hogg AG, Blackwell PG, Buck CE, Higham TFG, Reimer PJ (2004) SHCAL04 Southern Hemisphere calibration, 0-11.0 CAL KYR в.P. Radiocarbon 46:1,087-1,092

Miksic J (ed) (1996) Ancient history. Archipelago Press, Singapore

Naples ML, Keßler PJA (2005) Weeds of rain fed lowland rice fields of Laos and Cambodia. Illustrations, identification, and information retrieval, version 12, September 2005. http://www.nationaal herbarium.nl/Riceweedsweb/. Accessed $20 \mathrm{Feb} 2010$

Newton A, Thunell R, Stott L (2006) Climate and hydrographic variability in the Indo-Pacific Warm Pool during the last millennium. Geophys Res Lett 33:L19710. doi:10.1029/2006GL027234

Oppo DW, Rosenthal Y, Linsley BK (2009) 2,000-Year-long temperature and hydrology reconstructions from the Indo-Pacific warm pool. Nature 460:1,113-1,116

Page SE, Siegert F, Rieley JO, von Boehm H-D, Jaya A, Limin S (2002) The amount of carbon released from peat and forest fires in Indonesia during 1997. Nature 420:61-65

Pillar VD (1999) The bootstrapped ordination re-examined. J Veg Sci 10:895-902

Pillar VD (2006) MULTIV: multivariate exploratory analysis, randomization testing and bootstrap resampling; users guide $\mathrm{v}$. 2.4. UFRGS, Departamento de Ecologia, Porto Alegre

Powell JM (1970) Highland Papua New Guinea Pollen Flora II. In: Powell JM (ed) The impact of man on the vegetation of the Mt. Hagen region, New Guinea. Dissertation, Australian National University Canberra (extract at http://palaeoworks.anu.edu.au/ databases.html)

Stevenson J (2000) New Caledonia Pollen Flora. In: Stevenson J (ed) Late Quaternary environmental change and the impact of Melanesian colonisation in New Caledonia. Dissertation, University of New South Wales, Kensington (extract at http://palaeo works.anu.edu.au/databases.html)

Stuijts I-LM (1993) Late Pleistocene and Holocene vegetation of West Java, Indonesia. A. Balkema, Rotterdam

Stuiver M, Reimer PJ (1993) Extended C-14 data-base and revised Calib 3.0 C-14 age calibration program. Radiocarbon 35:215-230

Sukendar H (1980a) Mencari peniggalan nenek moyang, pendukung tradisi megalitik di Tanah Bada (Sulteng). Kalpataru 5:1-63

Sukendar H (1980b) Description of the megalithic tradition of Indonesia. Berkala Arkeologi VIII 1:1-30

Sukendar H (1997) Introduction/Central Sulawesi. Album - Tradisi Megalitik Di Indonesia. Album of megalithic tradition in Indonesia 11-18, pp 111-113

Suparan P, Dam RAC, van der Kaars S, Wong TE (2001) Late Quaternary tropical lowland environments on Halmahera, Indonesia. Palaeogeogr Palaeoclimatol Palaeoecol 171:229-258

The Nature Conservancy Indonesia Program (ca. 2004) Lore Lindu National Park: building partnerships to protect Sulawesi's unique wildlife. http://www.nature.org/wherewework/asiapacific/indonesia/ files/lore_lindu_summary.pdf. Accessed 24 Nov 2008

Tscharntke T, Leuschner C, Zeller M, Guhardja E, Bidin A (eds) (2007) The stability of tropical rainforest margins, linking ecological, economic and social constraints of land use and conservation. Springer, Berlin

Van der Kaars WA (1991) Palynology of eastern Indonesian marine piston-cores: a late quaternary vegetational and climatic record for Australasia. Palaeogeogr Palaeoclimatol Palaeoecol 85:239-302

Van der Kaars S (1998) Marine and terrestrial pollen records of the last glacial cycle from the Indonesian region: Bandung basin and Banda Sea. Palaeoclim Data Model 3:209-219

Van der Kaars S, van den Bergh GD (2004) Anthropogenic changes in the landscapes of west Java (Indonesia) during historic times, inferred from a sediment and pollen record from Teluk Banten. J Quat Sci 19(3):229-239

Van der Kaars S, Wang X, Kershaw AP, Guichard F, Setiabudi DA (2000) A late Quaternary palaeoecological record from the Banda Sea, Indonesia: patterns of vegetation, climate and biomass burning in Indonesia and northern Australia. Palaeogeogr Palaeoclimatol Palaeoecol 155:135-153

Van der Kaars S, Penny D, Tibby J, Fluin J, Dam RAC, Suparan P (2001) Late Quaternary palaeoecology, palynology and palaeolimnology of a tropical lowland swamp: Rawa Danau, West-Java, Indonesia. Palaeogeogr Palaeoclimatol Palaeoecol 171:185-212

Van der Kaars S, Tapper N, Cook EJ (2010) Observed relationships between El Niño-Southern Oscillation, rainfall variability and vegetation and fire history on Halmahera, Maluku, Indonesia. Glob Change Biol 16:1,705-1,714

Wang L, Sarntheim M, Erlenkeuser H, Grootes P, Grimalt JO, Pelejero C, Linck G (1999a) Holocene variations in Asian Monsoon moisture: a bidecadal sediment record from the South China Sea. Geophys Res Lett 26:2,889-2,892

Wang X, van der Kaars S, Kershaw AP, Bird M, Jansen F (1999b) A record of vegetation and climate through the last three glacial cycles from Lombok Ridge core G6-4, eastern Indian Ocean, Indonesia. Palaeogeogr Palaeoclimatol Palaeoecol 147:241-256

Watanabe T, Winter A, Oba T (2001) Seasonal changes in sea surface temperature and salinity during the Little Ice Age in the Caribbean Sea deduced from $\mathrm{Mg} / \mathrm{Ca}$ and ${ }^{18} \mathrm{O} /{ }^{16} \mathrm{O}$ ratios. Mar Geol 173:21-36

Weber S, Lehman H, Barela T, Hawks S, Harriman D (2010) Rice or millets: early farming strategies in prehistoric central Thailand. Archaeol Anthropol Sci. doi:10.1007/s12520-010-0030-3

Whitten A, Mustafa M, Henderson GS (1987) The ecology of Sulawesi. Periplus Editions, Singapore

Willis KJ, Gillson L, Brncic TM (2004) How "virgin" is virgin rainforest. Science 304:402-403

Yamasue Y, Ueki K (1983) Biology of paddy weeds and their control in wetland rice. In: Proceedings of the conference on weed control in rice, 31 August -4 September 1981, Manila, pp 228-242

Yulianto E, Rahardjo AT, Noeradi D, Siregar DA, Hirakawa K (2005) A Holocene pollen record of vegetation and coastal environmental changes in the coastal swamp forest at Batulicin, South Kalimantan, Indonesia. J Asian Earth Sci 25:1-8

Yuniawati DY (2001) Stone burials, one of the megalithic remains in Sulawesi. Asp Indones Archaeol 26:1-33

Zhao Z (2010) New data and new issues for the study of origin of rice agriculture in China. Archaeol Anthropol Sci. doi:10.1007/ s12520-010-0028-x 